\title{
THE IMPACT OF FINANCIAL TRANSACTIONS TAXES ON MONEY DEMAND IN COLOMBIA
}

\author{
Marcela Giraldo* \\ BRIAN W. BUCKLES ${ }^{* *}$
}

\begin{abstract}
Some countries in Latin America have introduced a tax on bank withdrawals in order to increase revenue. The debit tax has usually been levied in periods of economic turbulence. This paper analyzes the effects of such a tax on real cash holdings and on balances of different types of bank accounts in Colombia.

The paper analyzes data for the period 1994 to 2007 and then verifies the robustness of the model using only the data from 2000 to 2007 , thereby eliminating the economic crisis of the late 1990s. The results show that even though the tax caused a decrease in checking account balances, the changes produced in total balances of real cash after 2001 cannot be attributed to the debit tax. However, an increase in the rate of growth of savings account balances can be attributed to it, suggesting a substitution from checking toward savings accounts.
\end{abstract}

JEL clasification: G21, H20, N26, E41

Keywords: Debit tax, banking, Latin America, transaction tax, money demand

\section{INTRODUCTION}

In 1998 the national government of Colombia introduced a tax on any financial transaction that involves withdrawing money from a bank account. The tax, which is still in effect, was created to alleviate an increasing government debt and has changed from 0.2 percent to 0.3 percent to 0.4 percent of the transaction amount.

The international economic and financial crisis at the end of the 1990s affected countries from Russia to Latin America and produced a reduction in the capital flow into Colombia from developed countries. Investors became much more cautious. This decreased the amount of money in the economy and, as a consequence, interest rates went up. Lower investment also increased unemployment, and along with a crisis in the housing market, banks were left with a very high level of non-performing loans.

\footnotetext{
* Baylor University. E-mail address: marcela_giraldo@baylor.edu

** University of Texas at Dallas. E-mail address: buckles@utdallas.edu
} 
The debit tax on all transactions from bank accounts was decreed the same day the country declared a State of Economic and Social Emergency on November 16, 1998. The main purpose of the tax was to raise funds to avoid a financial crisis like those experienced in Chile in 1985, Venezuela in 1994, and Mexico in 1995. To contain the crisis, the Colombian government set some short-term goals including increasing the liquidity of the financial sector through actions of the central bank and strengthening the bank insurance fund (FOGAFIN). The tax in question was introduced in order to achieve the latter goal. ${ }^{1}$

This paper analyzes data from 1994 to 2007 on real cash holdings, total checking account deposits and total savings deposits (savings accounts and CDs). Taking advantage of the variations in the debit tax, the data set is analyzed in its entirety, and then only for the years following the economic crisis at the end of the 1990s. Surprisingly, the results show no significant effect on real cash holdings. The debit tax causes a significant decrease in checking account balances but no significant effect on savings, except for the second difference of savings, which shows a positive and significant coefficient beginning in 2000 .

Little research has been done previously on the effects of this tax. Coelho et al. (2001) highlight general statistical observations, political causes of the tax, and general ideas that future researchers should keep in mind when studying it. Their analysis looks at similar taxes implemented in other countries such as Argentina, Peru, Venezuela, and Brazil. Their IMF paper emphasizes the possible serious effects of taxing the financial sector (i.e., disintermediation), however, no econometric analysis is attempted. Other authors at the Colombian central bank, the Association of Banks (ASOBANCARIA), and the Tax Administration Department (DIAN) have studied the tax on financial transactions but without using econometric tools. There is no previous rigorous econometric analysis of which the authors are aware.

Other lines of research, such as that of Rodríguez (2002) and Clavijo (2005), focus on the distributional effect of the tax. Clavijo (2005) explains the distributional effects of different taxes, one of which is the tax on financial transactions. He concludes that the debit tax, contrary to the opinions of most politicians and researchers, is not necessarily progressive. Those who own large amounts of capital also have access to 
financial instruments that are not taxed; in particular, they can make transactions using accounts outside Colombia. Rather, it is small and medium businesses who bear most of the burden. Rodríguez (2002) concludes that the tax is progressive, but only for some periods of time. In other words, its distributional effect is not consistent. This paper contributes to previous research by relying on more years of data and by applying rigorous econometric techniques.

\section{History OF THE TAX ON FINANCIAL TRANSACTIONS}

In November of 1998 the Colombian government established the debit tax. It was announced as a temporary tax (from December 1, 1998 until December 31, 1999). The rate was set at 0.2 percent on all transactions from savings or checking accounts and 0.12 percent on interbank transactions, except those with the central bank.

In January of 1999 the tax rate became uniform for all transactions, at 0.2 percent. Later in the same month, the tax was extended through December 2000, and the tax for interbank transactions in national currency was eliminated due to its devastating effect on the interbank market. ${ }^{2}$ The following month the government decided that the revenue from the debit tax was to be used to rebuild the area of the country affected by a devastating earthquake.

In December of 2000 the tax became permanent and the rate was increased to 0.3 percent. This came as no surprise given that the tax had become a reliable and easily collectible source of revenue. Three years later the tax rate was increased temporarily to 0.4 percent for the years 2004 to 2007 , and was scheduled to return to 0.3 percent in 2008. Instead, in 2006 the increased tax rate of 0.4 percent was made permanent.

In summary, the tax rate was increased three times. The first time, in December of 1998, it was increased from 0 percent (nonexistent) to 0.2 percent. The other two changes, in January of 2001 (approved in December of 2000) and in January of 2004 each consisted of an increase of 0.1 percentage points.

It is important to note that currently some transactions are exempt from the tax. Each account holder may choose one savings account 
from which he or she is allowed to withdraw up to $350 \mathrm{UVT}^{3}$ per month, or approximately 2,748 US dollars (in 1998 dollars). ${ }^{4}$ Individuals with a pension may choose a second savings account in which they deposit their pension for an exemption of $41 \mathrm{UVT}$, equivalent to 322 US dollars (in 1998 dollars). ${ }^{5}$

\section{THEORETICAL BACKGROUND}

Several articles have looked at the general concept of transaction costs and their implications for money demand. Some examples include Saving (1971 and 1976) and Barro (1976). In this section we will adapt the substitution analysis in Saving (1971) to the case of the transaction tax. In particular, it is necessary to consider that agents may now be substituting among different ways of holding money, as the relative cost of using bank deposits has increased.

The creation of a tax may have two different effects on decision making. First, individuals may be substituting away from the use of bank deposits in favor of cash holdings, as the relative cost of the former has increased. When the exemptions from the tax were introduced for savings accounts, this same substitution effect would cause an increase in the use of such accounts. Second, the increase in the tax implies that individuals have less total income, and hence the total value of transactions in the economy might decrease along with the demand for all types of money. This income effect occurs when individuals who are remunerated through a bank decide to decrease the total amount of money withdrawn (as total consumption decreases).

The substitution effect between using bank accounts or holding cash may be very small or nonexistent, depending on whether the use of deposit accounts can indeed be substituted for cash. In Colombia, there are many fees for using banking services, in addition to the transaction tax. Therefore, it is very likely that most individuals using banking services do so because they conduct larger transactions for which the use of cash is very difficult and even dangerous. Viewed differently, the absence of any substitution effect that increases the use of cash is economically important because it indicates that agents who really need the banking sector inside the country are those burdened the most by the tax.

3. UVT stands for tax unit value. It is a unit created by the DIAN that changes with inflation and is used in tax legislation. The actual value of the UVT amount specified in regulations changes each year.

4. This is equivalent to approximately 3.500 US dollars in 2007.

5. See Table A1 for a history of the exemptions. 


\section{DATA}

All data was obtained from the central bank of Colombia (Banco de la República), except for the inflation rate, which was gathered from the Department of National Statistics (DANE). The variables are all real with a base period of December 1998. All series are monthly and run from January 1994 to December 2007.

Three measures of money are analyzed: cash holdings, checking account deposits, and balances in M2 not included in M1. Based on the definition used in Colombia, M2-M1 equates to savings accounts and all CDs.

As explained previously, the tax on financial transactions reduces the return on bank deposits, which should generate a preference for cash holdings and financial investments that are not subject to the tax. ${ }^{6}$ This paper evaluates the existence of such a substitution effect, as well as the existence of any income effect.

Previous literature such as Barro (1976) and Labán (1991) has recognized the relationship between demand for money, expenditure levels, and interest rates. Consequently, this paper is based on a vector autoregression (VAR) model that allows all three variables to be jointly determined in equilibrium. As real GNP increases, it is expected that more money is used to carry out transactions. For this reason GNP is one of the dependent variables that is determined together with interest rates and money demand.

However, not only is the general level of production in the country relevant, but also who has the money. Because sectors such as industry and services tend to have more access to capital sources outside the banking sector than production generated in agriculture, the variable agro/GNP is included as an exogenous variable to control for the percentage of GNP that comes from agriculture. It should be kept in mind that this paper evaluates the use of different measures of money, which depends on the needs and preferences of various sectors of the economy.

Real minimum wage is also included in the model to control for the size of the transactions that most individuals perform. This is because the size of the transactions may affect the substitutability of banking 
services. In Colombia, where most individuals earn the minimum wage or less, ${ }^{7}$ the lower the real minimum wage, the lower we can expect the average transaction size to be in the country.

In addition to the aforementioned explanatory variables, the VAR includes the tax rate on financial transactions and the optimal number of lags of each dependent variable as indicated by different information criteria.

\section{ECONOMETRIC MODELS}

\subsection{Model A}

The first model uses a variable called $\Delta$ tax which is simply the annual change in the tax rate.

The basic specification is as follows:

$$
\bar{y}_{t}=A+\sum_{s=1}^{p} B_{s} \bar{y}_{t-s}+C \bar{X}_{t}+D \Delta \operatorname{tax}_{t}+E \Delta \operatorname{tax} 01_{t}+\bar{\varepsilon}_{t}
$$

where $\bar{y}_{t}$ is a vector comprised of the following three jointly determined variables: the measure of money, the interest rate, and GNP. $\bar{Y}_{t-s}$ is that same vector lagged $s$ months, up to the appropriate number $p .^{8}$ The vector $\bar{X}_{t}$ includes the exogenous variables, namely the percentage of GNP that comes from agriculture and the real minimum wage. $\Delta \operatorname{tax}_{t}$ is the annual change in the tax rate, and $\Delta \operatorname{tax} 01_{t}$ is equal to $\Delta \operatorname{tax}_{t} \times d_{2001}$, where $d_{2001}$ is a dummy equal to one beginning in January of 2001. Hence, the effect of the tax beginning in 2001 is equal to $D+E \cdot \bar{\varepsilon}_{t}$ is the error vector.

The interaction term on the tax rate variable is introduced because it is possible that the effect of the tax is different beginning in 2001, for each percentage point change. In January of that year the tax became permanent, the second rate change was introduced (the increase to 0.3 percent), and the exemption on some savings accounts took effect. If the tax was to be temporary, some individuals might have opened CDs with the intention of using that money later when the

7. There is a large informal (unreported) sector in Colombia.

8. The specification maintains the standard assumption of lag order symmetry. 
tax had expired, thereby increasing the expected balances of M2-M1. A permanent tax could reverse such an effect. On the other hand, an exemption for savings accounts reduces the cost of holding bank deposits, thereby decreasing the expected substitution effect of the tax beginning in 2001.

The aforementioned VAR model is run four times with the following measures of money demand: the rate of growth in real cash holdings, the rate of growth of checking account deposits, the second difference $\left(\Delta^{2}\right)$ of the $\ln (\mathrm{M} 2-\mathrm{M} 1)$, and a transformed first difference $(\Delta)$ of the $\ln (\mathrm{M} 2-\mathrm{M} 1)$ that is explained in the next section. ${ }^{9}$

\subsection{Model B}

Coelho et al. (2001) warn researchers to exercise caution when drawing conclusions from data on Latin America for the last years of the 1990s. The economic crisis of that period created high levels of instability, so isolating tax effects and exogenous macroeconomic changes may not be possible. This paper analyzes more years of information, however, and the tax rate varied considerably after the 1990s. Even if the effects of the tax cannot be separated from the macroeconomic turbulence of the late 1990s, it is still possible to learn about these effects by focusing on changes in money demand caused by the increase in the tax rate after the crisis ended. By 2001, GNP in Colombia was growing steadily and the country was more stable politically and economically. Thus, to account for a structural change during the period of economic turmoil, Model B is included in the analysis. Model B is identical to Model A except that the data begins in January of 2000, when the first positive GNP growth occurred.

\section{Preliminary tests}

As with any time series data, stationarity must be evaluated. The Dickey-Fuller Test with trend and constant is used to determine the existence of unit roots. Nonstationary variables are differenced. The results of the tests are reported in Table 1.

In summary, the following variables are established as stationary: the first difference of the natural $\log$ of real cash holdings $(\Delta \ln ($ cash $))$, 
Table 1. Dickey-Fuller tests

\begin{tabular}{|lcc|}
\hline & $p$-value for $Z(t)$ & No Observations \\
\hline$\Delta \ln ($ cash $)$ & 0.0052 & 155 \\
\hline$\Delta \ln ($ checking $)$ & 0.0697 & 155 \\
\hline$\Delta \ln (\mathrm{M} 2-\mathrm{M} 1)$ & 0.3928 & 155 \\
$\quad$ Transf(M2-M1) & 0.0000 & 155 \\
$\Delta^{2} \ln (\mathrm{M} 2-\mathrm{M} 1)$ & 0.0000 & 154 \\
\hline$\Delta \ln (\mathrm{r})$ & 0.6416 & 105 \\
$\Delta^{2} \ln (\mathrm{r})$ & 0.0000 & 104 \\
\hline$\Delta \ln (\mathrm{GNP})$ & 0.3765 & 155 \\
$\Delta^{2} \ln (\mathrm{GNP})$ & 0.0000 & 154 \\
\hline$\Delta^{(\text {agro } / \text { GNP })}$ & 0.0404 & 155 \\
\hline$\Delta^{\ln (\text { wage })}$ & 0.2279 & 155 \\
$\Delta^{2} \ln ($ wage $)$ & 0.0000 & 154 \\
\hline
\end{tabular}

which is interpreted as the annual rate of growth of real cash holdings; the annual rate of growth in checking accounts $(\Delta \ln$ (checking)); the difference of the annual growth rate of the interest rate for consumer loans $\left(\Delta^{2} \ln (\mathrm{r})\right)$, hereafter referred to as the "second difference"; the second difference of the natural log of GNP $\left(\Delta^{2} \ln (\mathrm{GNP})\right)$; the annual difference of agro/GNP $(\Delta$ (agro/GNP $))$; and the second difference of the natural $\log$ of the real minimum wage $\left(\Delta^{2} \ln (\right.$ wage $\left.)\right)$.

The annual difference of the natural $\log$ of $\mathrm{M} 2-\mathrm{M} 1$, which is interpreted as the rate of growth of savings, is not stationary. However, second-differencing it to achieve stationarity would compromise the interpretation of the coefficients and prevent verification of the existence of an income effect or a substitution effect. In this context, the second difference is the change in the rate of growth of the variable, and it does not indicate whether the variable is increasing or decreasing but whether the change occurs faster or slower in response to movement of an exogenous variable. For this reason, we create a transformed variable by applying a refined Hanning linear smoother to the series. ${ }^{10}$ The stationary difference between the actual 
observation and the smoothed series is used as a dependent variable, and interpreted as the part of M2-M1 that is not explained by its trend. The second difference is still used in some regressions, despite limitations on the interpretation of its results.

Summary statistics for all variables are found in Table 2. Figures 1 through 3 display the history of the different measures of money demand evaluated in this paper. The three vertical lines in each figure correspond to December of 1998 when the tax came into existence, January of 2001 when the tax was first increased, and January of 2004 when the second increase occurred.

Table 2. Summary statistics

\begin{tabular}{|c|c|c|c|c|}
\hline & Mean & Std. dev. & Min & Max \\
\hline$\Delta \ln (\operatorname{cash})$ & 0.1231 & 0.0527 & 0.0096 & 0.2548 \\
\hline$\Delta \ln ($ checking $)$ & 0.0245 & 0.1256 & -0.2992 & 0.3015 \\
\hline$\Delta \ln (\mathrm{M} 2-\mathrm{M} 1)$ & 0.0476 & 0.0797 & -0.1103 & 0.2302 \\
\hline Transf(M2-M1) & -0.0001 & 0.0126 & -0.0458 & 0.0453 \\
\hline$\Delta^{2} \ln (\mathrm{M} 2-\mathrm{M} 1)$ & -0.0004 & 0.0193 & -0.0616 & 0.0537 \\
\hline$\Delta \ln (\mathrm{r})$ & -0.0898 & 0.1993 & -0.7456 & 0.3734 \\
\hline$\Delta^{2} \ln (\mathrm{r})$ & 0.0045 & 0.0577 & -0.2279 & 0.2429 \\
\hline$\Delta \ln (\mathrm{GNP})$ & 0.0308 & 0.0324 & -0.0706 & 0.0806 \\
\hline$\Delta^{2} \ln (\mathrm{GNP})$ & 0.0015 & 0.0090 & -0.0379 & 0.0382 \\
\hline$\Delta($ agro $/ \mathrm{GNP})$ & -0.0027 & 0.0032 & -0.0080 & 0.0050 \\
\hline$\Delta \ln ($ wage $)$ & 0.0122 & 0.0163 & -0.0198 & 0.0643 \\
\hline$\Delta^{2} \ln ($ wage $)$ & -0.0006 & 0.0057 & -0.0440 & 0.0076 \\
\hline$\Delta \operatorname{tax}$ & 0.0333 & 0.0569 & 0.0000 & 0.2000 \\
\hline$\Delta \operatorname{tax} 01$ & 0.0235 & 0.0426 & 0.0000 & 0.1000 \\
\hline
\end{tabular}


Figure 1. Real cash holdings

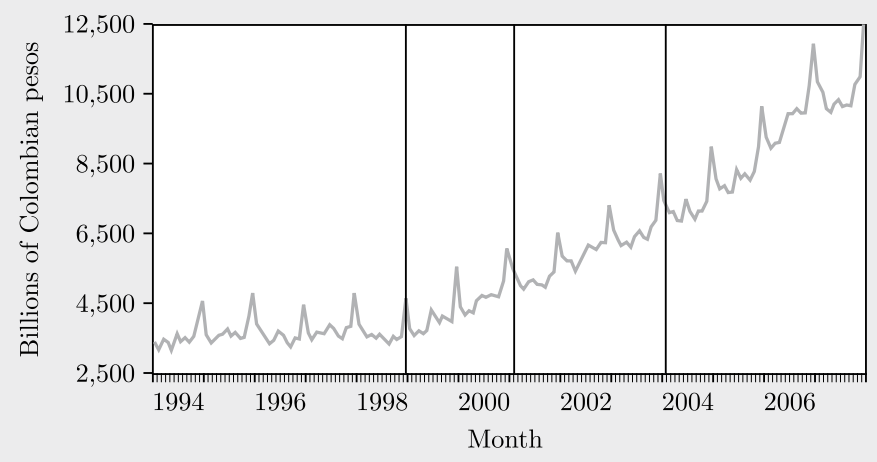

Source: Banco de la República, Colombia.

Figure 2. Real checking account deposits

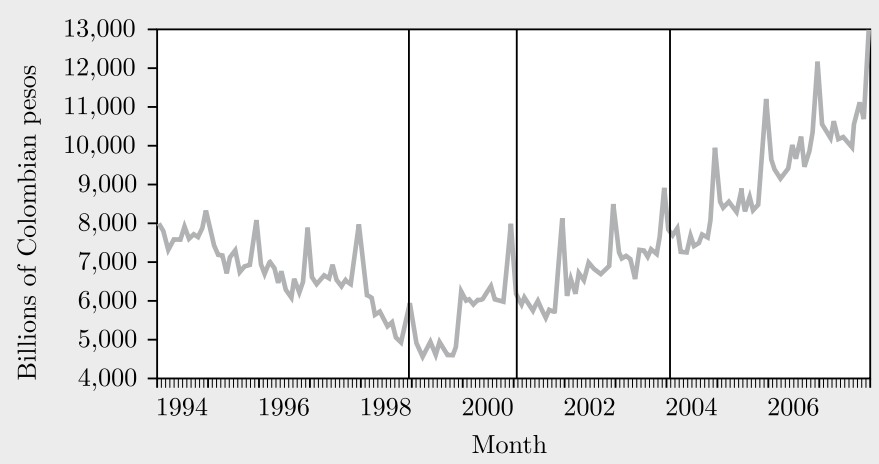

Source: Banco de la República, Colombia.

Figure 3. Real savings account deposits and CDs

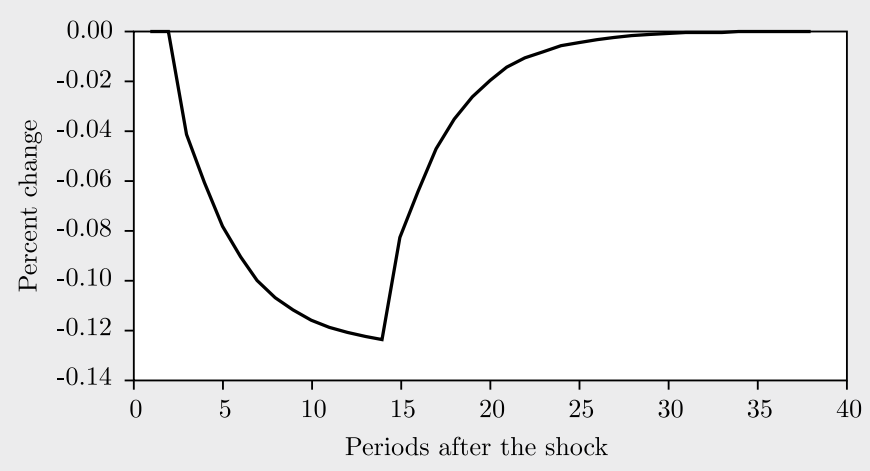


The common selection order criteria for determining the optimal number of lags of the dependent variables are displayed in Tables 3 through 6 . A different measure of money demand is used in each table. The tests include the likelihood-ratio test (LR), the final prediction error (FPE), and the information criteria developed by Akaike (AIC), Hannan and Quinn (HQIC), and Schwarz (SBIC). The latter's tendency to underfit is evident for all measures of money demand. The preferred criteria for a small sample size are the AIC and FPE, which agree in suggesting optimal lags of four when the measure of money demand is real cash holdings and two for all other measures of money demand.

\section{Table 3. Selection order criteria for real cash holdings}

(Measure of money demand)

\begin{tabular}{ccccccccc}
\hline lag & $\mathbf{L L}$ & $\mathbf{L R}$ & $\mathbf{d f}$ & $\mathbf{p}$ & $\mathbf{F P E}$ & AIC & HQIC & SBIC \\
\hline 0 & 645.447 & & & & $5.9 \mathrm{e}-10$ & -12.7363 & -12.5772 & -12.3431 \\
1 & 691.585 & 92.276 & 9 & 0.000 & $2.8 \mathrm{e}-10$ & -13.4866 & $-13.232^{*}$ & $-12.8574^{*}$ \\
2 & 700.650 & 18.131 & 9 & 0.034 & $2.8 \mathrm{e}-10$ & -13.4879 & -13.1379 & -12.6228 \\
3 & 714.073 & 26.845 & 9 & 0.001 & $2.6 \mathrm{e}-10$ & -13.5772 & -13.1318 & -12.4763 \\
4 & 729.745 & 31.345 & 9 & 0.000 & $2.2 \mathrm{e}-10^{*}$ & $-13.712^{*}$ & -13.1711 & -12.3751 \\
5 & 734.964 & 10.438 & 9 & 0.316 & $2.4 \mathrm{e}-10$ & -13.6356 & -12.9993 & -12.0628 \\
6 & 743.622 & $17.316^{*}$ & 9 & 0.044 & $2.5 \mathrm{e}-10$ & -13.6287 & -12.8969 & -11.8200 \\
\hline
\end{tabular}

Table 4. Selection order criteria for real checking account deposits

(Measure of money demand)

\begin{tabular}{|ccccccccc|}
\hline lag & LL & LR & df & $\mathbf{p}$ & FPE & AIC & HQIC & SBIC \\
\hline 0 & 628.493 & & & & $8.3 \mathrm{e}-10$ & -12.3938 & -12.2347 & -12.0006 \\
1 & 677.253 & 97.519 & 9 & 0.000 & $3.7 \mathrm{e}-10$ & -13.1970 & $-12.9425^{*}$ & $-12.5679^{*}$ \\
2 & 688.534 & $22.563^{*}$ & 9 & 0.007 & $3.6 \mathrm{e}-10^{*}$ & $-13.2431^{*}$ & -12.8931 & -12.3781 \\
3 & 691.911 & 6.7546 & 9 & 0.663 & $4.0 \mathrm{e}-10$ & -13.1295 & -12.6841 & -12.0286 \\
4 & 696.701 & 9.5802 & 9 & 0.386 & $4.4 \mathrm{e}-10$ & -13.0445 & -12.5036 & -11.7076 \\
5 & 701.889 & 10.375 & 9 & 0.321 & $4.8 \mathrm{e}-10$ & -12.9675 & -12.3311 & -11.3947 \\
6 & 709.227 & 14.676 & 9 & 0.100 & $5.0 \mathrm{e}-10$ & -12.9339 & -12.2021 & -11.1252 \\
\hline
\end{tabular}

Endogenous: $\Delta \ln$ (checking) $\Delta^{2} \ln (\mathrm{r}) \Delta^{2} \ln (\mathrm{GNP})$ Exogenous: $\Delta$ (agro/GNP) $\Delta^{2} \ln ($ wage $) \Delta \operatorname{tax} . \Delta \operatorname{tax} 01$.

$*$ denotes optimal number of lags.

Number of obs $=99$. 
Table 5. Selection order criteria for real savings account deposits and CDs (Transformed)

(Measure of money demand)

\begin{tabular}{|c|c|c|c|c|c|c|c|c|}
\hline lag & LL & LR & df & $\mathbf{p}$ & FPE & AIC & HQIC & SBIC \\
\hline 0 & 787.566 & & & & $3.3 e-11$ & -15.6074 & -15.4483 & $-15.2142^{*}$ \\
\hline 1 & 805.363 & 35.595 & 9 & 0.000 & $2.8 \mathrm{e}-11$ & -15.7851 & $-15.5306^{*}$ & -15.1560 \\
\hline 2 & 817.495 & 24.263 & 9 & 0.004 & $2.6 \mathrm{e}-11^{*}$ & $-15.8484^{*}$ & -15.4984 & -14.9833 \\
\hline 3 & 820.897 & 6.8046 & 9 & 0.657 & $3.0 \mathrm{e}-11$ & -15.7353 & -15.2898 & -14.6343 \\
\hline 4 & 828.914 & 16.034 & 9 & 0.066 & $3.0 \mathrm{e}-11$ & -15.7154 & -15.1745 & -14.3786 \\
\hline 5 & 834.244 & 10.66 & 9 & 0.300 & $3.3 \mathrm{e}-11$ & -15.6413 & -15.0049 & -14.0685 \\
\hline 6 & 844.281 & $20.073^{*}$ & 9 & 0.017 & $3.2 \mathrm{e}-11$ & -15.6622 & -14.9304 & -13.8535 \\
\hline \multicolumn{9}{|c|}{$\begin{array}{l}\text { Endogenous: Transf(M2-M1) } \Delta^{2} \ln (\mathrm{r}) \Delta^{2} \ln (\mathrm{GNP}) \\
{ }^{*} \text { denotes optimal number of lags. } \\
\text { Number of obs }=99\end{array}$} \\
\hline
\end{tabular}

Table 6. Selection order criteria for real savings account deposits and CDs (second difference)

(Measure of Money Demand)

\begin{tabular}{|ccccccccc}
\hline lag & $\mathbf{L L}$ & $\mathbf{L R}$ & $\mathbf{d f}$ & $\mathbf{p}$ & $\mathbf{F P E}$ & AIC & HQIC & SBIC \\
\hline 0 & 753.305 & & & & $6.7 \mathrm{e}-11$ & -14.9153 & -14.7562 & $-14.5221^{*}$ \\
1 & 768.860 & 31.11 & 9 & 0.000 & $5.9 \mathrm{e}-11$ & -15.0477 & $-14.7931^{*}$ & -14.4186 \\
2 & 779.096 & $20.472^{*}$ & 9 & 0.015 & $5.7 \mathrm{e}-11^{*}$ & $-15.0727^{*}$ & -14.7227 & -14.2076 \\
3 & 783.930 & 9.668 & 9 & 0.378 & $6.2 \mathrm{e}-11$ & -14.9885 & -14.543 & -13.8875 \\
4 & 788.841 & 9.821 & 9 & 0.365 & $6.8 \mathrm{e}-11$ & -14.9059 & -14.365 & -13.569 \\
5 & 795.770 & 13.859 & 9 & 0.127 & $7.2 \mathrm{e}-11$ & -14.864 & -14.2277 & -13.2912 \\
6 & 801.309 & 11.077 & 9 & 0.270 & $7.7 \mathrm{e}-11$ & -14.7941 & -14.0623 & -12.9854 \\
\hline
\end{tabular}

\section{RESUlts}

\subsection{Model A}

Tables 7 through 10 show the effect of the tax during the crisis. When the tax was introduced in 1999, it had an important stabilizing effect on the financial sector. Its purpose was to generate funds to avoid a financial crisis of major proportions, and that goal was achieved. This is evident in this data, as three of the four regressions in Model A indicate that the introduction of the tax contributed to a consistently higher change in GNP growth. In 1999, GNP growth was negative, implying that the 
decrease in GNP was smaller than it would have been without the tax. Specifically, a 0.1 point increase in the tax rate is associated with an increase in the rate of growth of GNP of 0.46 to 0.57 percent. However, this effect is short-lived. As soon as the tax becomes permanent, the negative sign on the $\Delta \operatorname{tax} 01$ interaction variable eliminates the initial effect. Beginning in 2000, the total effect of the tax rate increases on the changes in GNP growth rates is statistically insignificant.

Note that the coefficients on the tax variables reported in Tables 7 through 14 are not elasticities. This paper measures the relative effect of each change in the tax, which was always a 0.1 percentage point increase after its introduction; the tax increased from 0.2 percent to 0.3 percent and then to 0.4 percent. It does not measure the effect of a percent increase in the tax rate, because the goal is to estimate the expected impact of yet another increase of 0.1 points by the government.

Cárdenas (2001a, 2001b) shows that real cash holdings have increased considerably after the tax on financial transactions was introduced in December 1998 (see Figure 1); however, she relies only on statistics. According to Table 7, there is no evidence that the tax caused the increase. In fact, real cash holdings decreased in response to the introduction of the tax, indicating that there was no substitution of balances in bank accounts for cash. A 0.1 point increase in the tax rate reduced the growth rate of real cash holdings by 1.72 percent. Moreover, in Model A there is no increase in checking account balances and no estimated effect on savings accounts. Tables 9 and 10 indicate that both measures of change in savings accounts were unaffected by the tax, even when it was introduced.

One possible explanation for this result is that the income effect dominates the substitution effect, as individuals demanded less of all types of money due to fewer transactions. A second, and more likely, explanation is that more transactions were performed using international markets or other institutions not subject to the tax. ${ }^{11}$ It is possible that some of the balances were directed into illegal channels. A series of Ponzi schemes flourished in Colombia in the early 2000s and started collapsing only in 2008. The "pyramids" collected deposits of individuals from all economic classes, with the poor being the most affected. After the "pyramids" collapsed, individuals blamed 
the government and the banking sector because, they argued, using banking services had become too expensive.

The coefficient on the interaction term, $\Delta$ tax01, is statistically zero for the dependent variable representing the growth rate of real cash holdings (Table 7). This result indicates that after the tax became permanent, increases in the tax did not cause any additional change in agents' behavior compared to their behavior while it was temporary. A plausible explanation is that the tax was never perceived as being temporary.

Table 7. Model A: VAR with $\Delta \ln ($ cash) as a measure of money demand

\begin{tabular}{|c|c|c|c|}
\hline \multirow{2}{*}{$\begin{array}{l}\text { VAR w/ } \Delta \ln (\text { cash }) \\
\text { Lags and exogenous vars }\end{array}$} & \multicolumn{3}{|c|}{ Dependent variables } \\
\hline & $\Delta \ln ($ cash $)$ & $\Delta^{2} \ln (r)$ & $\Delta^{2} \ln (\mathrm{GNP})$ \\
\hline L4. $\Delta \ln ($ cash $)$ & $-0.3302 * * *$ & -0.1225 & 0.0055 \\
\hline L3. $\Delta \ln ($ cash $)$ & $0.3811 * * *$ & 0.2647 & -0.0020 \\
\hline L2. $\Delta \ln ($ cash $)$ & $0.2165 * *$ & -0.1510 & -0.0340 \\
\hline L1. $\Delta \ln ($ cash $)$ & $0.5220 * * *$ & 0.1399 & 0.0257 \\
\hline L4. $\Delta^{2} \ln (r)$ & $0.1844 * * *$ & -0.0538 & 0.0041 \\
\hline L3. $\Delta^{2} \ln (r)$ & $-0.1820 * * *$ & 0.0399 & -0.0127 \\
\hline L2. $\Delta^{2} \ln (r)$ & 0.0734 & 0.0758 & 0.0009 \\
\hline L1. $\Delta^{2} \ln (r)$ & -0.1026 & $0.2833 * *$ & 0.0021 \\
\hline L4. $\Delta^{2} \ln (\mathrm{GNP})$ & $0.9501 * *$ & -0.8653 & -0.0890 \\
\hline L3. $\Delta^{2} \ln (\mathrm{GNP})$ & $1.0599 * * *$ & 0.0371 & -0.0954 \\
\hline L2. $\Delta^{2} \ln (\mathrm{GNP})$ & 0.1272 & 0.3687 & -0.0694 \\
\hline L1. $\Delta^{2} \ln (\mathrm{GNP})$ & 0.0036 & -0.6644 & -0.1103 \\
\hline$\Delta($ agro/GNP $)$ & 1.7525 & $4.3427 * *$ & -0.2197 \\
\hline$\Delta^{2} \ln ($ wage $)$ & 0.8974 & 1.3213 & -0.2389 \\
\hline$\Delta \operatorname{tax}$ & $-0.1716^{*}$ & -0.1016 & $0.0464 *$ \\
\hline$\Delta \operatorname{tax} 01$ & 0.1086 & -0.0403 & $-0.0699 *$ \\
\hline Constant & $0.0305 * * *$ & 0.0069 & 0.0017 \\
\hline Pseudo- $R^{2}$ & 0.7176 & 0.3551 & 0.0982 \\
\hline$p$-value for $F$ statistic & 0.0000 & 0.0008 & 0.8965 \\
\hline
\end{tabular}


Model A shows that a 0.1 point increase in the tax rate caused a 5.4 percent decrease in the rate of growth of checking accounts (Table 8). ${ }^{12}$ This may be caused by an income effect; however, the tax's effect on real cash holdings should be of a similar magnitude for such an explanation to be plausible. It is more likely that some of the transactions previously handled through checking accounts are now being performed either outside the country or through other channels not subject to the tax. The results suggest that there was some disintermediation caused by the tax on financial transactions. Our finding is in accordance with statistics recorded previously (Cárdenas, 2001 b and 2002) on the significant decrease in the number of checks cleared by the central bank after the tax was created.

\section{Table 8. Model A: VAR with $\Delta \ln ($ checking) as a measure of money demand}

\begin{tabular}{|c|c|c|c|}
\hline \multirow{2}{*}{$\begin{array}{l}\text { VAR } \mathrm{w} / \Delta \ln \text { (checking) } \\
\text { Lags and exogenous vars }\end{array}$} & \multicolumn{3}{|c|}{ Dependent variables } \\
\hline & $\Delta \ln ($ checking $)$ & $\Delta^{2} \ln (r)$ & $\Delta^{2} \ln (\mathrm{GNP})$ \\
\hline L2. $\Delta \ln$ (checking) & $0.2095 * *$ & $0.2003 * *$ & -0.0105 \\
\hline L1. $\Delta \ln$ (checking) & $0.4433 * * *$ & 0.1230 & -0.0044 \\
\hline L2. $\Delta^{2} \ln (r)$ & 0.0195 & 0.0544 & -0.0037 \\
\hline L1. $\Delta^{2} \ln (r)$ & -0.1107 & $0.2480 * * *$ & -0.0027 \\
\hline L2. $\Delta^{2} \ln (\mathrm{GNP})$ & 0.7894 & 0.7461 & -0.0801 \\
\hline L1. $\Delta^{2} \ln (\mathrm{GNP})$ & -0.2009 & -0.5555 & -0.1389 \\
\hline$\Delta($ agro/GNP $)$ & $4.0221 * *$ & 1.7512 & -0.0232 \\
\hline$\Delta^{2} \ln ($ wage $)$ & $-1.4190 *$ & 0.1362 & -0.1838 \\
\hline$\Delta \operatorname{tax}$ & $-0.5367 * * *$ & 0.1453 & 0.0348 \\
\hline$\Delta \operatorname{tax} 01$ & 0.1027 & -0.0124 & $-0.0687 * *$ \\
\hline Constant & $0.0568 * * *$ & $-0.0240 * *$ & 0.0032 \\
\hline Pseudo- $R^{2}$ & 0.7620 & 0.4487 & 0.1304 \\
\hline$p$-value for $F$ statistic & 0.0000 & 0.0000 & 0.1165 \\
\hline
\end{tabular}

12. This effect did not change after 2000. Subsequent increases in the tax continued to have the same effect when the tax was permanent as when it was temporary. Again, this can be explained by the tax never being perceived as temporary. 
Table 9. Model A: VAR with transf(M2-M1) as a measure of money demand

\begin{tabular}{|c|c|c|c|}
\hline \multirow{2}{*}{$\begin{array}{l}\text { VAR w/ Transf(M2-M1) } \\
\text { Lags and exogenous vars }\end{array}$} & \multicolumn{3}{|c|}{ Dependent variables } \\
\hline & Transf(M2-M1) & $\Delta^{2} \ln (r)$ & $\Delta^{2} \ln (\mathrm{GNP})$ \\
\hline L2. Transf(M2-M1) & $-0.2850 * * *$ & 0.1700 & 0.0451 \\
\hline L1. Transf(M2-M1) & $0.3504 * * *$ & 0.3089 & $-0.1277^{*}$ \\
\hline L2. $\Delta^{2} \ln (r)$ & -0.0343 & 0.1032 & -0.0065 \\
\hline L1. $\Delta^{2} \ln (r)$ & -0.0284 & $0.3655 * * *$ & -0.0085 \\
\hline L2. $\Delta^{2} \ln (\mathrm{GNP})$ & $-0.3271 * * *$ & $1.0263 *$ & -0.0949 \\
\hline L1. $\Delta^{2} \ln (\mathrm{GNP})$ & -0.1465 & -0.2862 & -0.1520 \\
\hline$\Delta($ agro/GNP $)$ & 0.0260 & $3.5960 * *$ & -0.0748 \\
\hline$\Delta^{2} \ln ($ wage $)$ & -0.1110 & 0.6223 & -0.2202 \\
\hline$\Delta \operatorname{tax}$ & 0.0132 & $-0.2532 * *$ & $0.0505^{* *}$ \\
\hline$\Delta \operatorname{tax} 01$ & -0.0386 & 0.1713 & $-0.0754 * * *$ \\
\hline Constant & 0.0017 & $0.0158 * *$ & 0.0015 \\
\hline Pseudo- $R^{2}$ & 0.2320 & 0.3407 & 0.1477 \\
\hline$p$-value for $F$ statistic & 0.0006 & 0.0000 & 0.0575 \\
\hline
\end{tabular}

Table 10. Model A: VAR with $\Delta^{2} \ln (\mathrm{M} 2-\mathrm{M} 1)$ as a measure of money demand

\begin{tabular}{|c|c|c|c|}
\hline \multirow{2}{*}{$\begin{array}{l}\text { VAR w/ } \Delta^{2} \ln (\mathrm{M} 2-\mathrm{M} 1) \\
\text { Lags and exogenous vars }\end{array}$} & \multicolumn{3}{|c|}{ Dependent variables } \\
\hline & $\Delta^{2} \ln (\mathrm{M} 2-\mathrm{M} 1)$ & $\Delta^{2} \ln (r)$ & $\Delta^{2} \ln ($ GNP $)$ \\
\hline L2. $\Delta^{2} \ln (\mathrm{M} 2-\mathrm{M} 1)$ & $-0.2943 * * *$ & -0.2017 & -0.0751 \\
\hline L1. $\left.\Delta^{2} \ln (\mathrm{M} 2-\mathrm{M} 1)\right)$ & 0.0004 & 0.1466 & $-0.0890 *$ \\
\hline L2. $\Delta^{2} \ln (r)$ & $0.0690 * *$ & 0.1049 & 0.0003 \\
\hline L1. $\Delta^{2} \ln (r)$ & 0.0177 & $0.3643 * * *$ & -0.0030 \\
\hline L2. $\Delta^{2} \ln (\mathrm{GNP})$ & -0.1890 & $0.9543 *$ & -0.0880 \\
\hline L1. $\Delta^{2} \ln (\mathrm{GNP})$ & -0.1429 & -0.4577 & $-0.1742 *$ \\
\hline$\Delta($ agro $/ \mathrm{GNP})$ & -0.2889 & $3.5222 * *$ & -0.1489 \\
\hline$\Delta^{2} \ln ($ wage $)$ & -0.0785 & 0.4692 & $-0.2820 *$ \\
\hline$\Delta \operatorname{tax}$ & 0.0478 & $-0.2469 * *$ & $0.0569 * * *$ \\
\hline$\Delta \operatorname{tax} 01$ & 0.0591 & 0.1512 & $-0.0661 * *$ \\
\hline Constant & -0.0018 & $0.0165^{* *}$ & 0.0011 \\
\hline Pseudo- $R^{2}$ & 0.1835 & 0.3394 & 0.1682 \\
\hline$p$-value for $F$ statistic & 0.0102 & 0.0000 & 0.0223 \\
\hline \multicolumn{4}{|c|}{ Statistically significant at the $1 \%$ level $(* * *)$, at the $5 \%$ level $(* *)$, and at the $10 \%$ level $(*)$. } \\
\hline
\end{tabular}




\subsection{Model B}

Model B focuses only on observations starting in the year 2000, when GNP growth became positive. Since then, the country has been more stable economically and politically. Any change in the tax rate during this period was a change in a permanent tax.

The results for Model B show that beginning in the year 2000, changes in the tax have no effect on real cash holdings (Table 11). The results for the growth rate of checking account balances are very similar in sign and magnitude to those discussed for Model A.

The variable $\Delta \operatorname{tax}$ is significant when the measure of money demand is the growth rate of checking account balances and the second difference of $\ln (\mathrm{M} 2-\mathrm{M} 1)$ (Tables 12 and 14, respectively). The most important difference between Models A and B is the sign of the coefficient of $\Delta$ tax for changes in the growth rate of savings accounts. In Model $\mathrm{B}$ this is positive, indicating that an increase of 0.1 points in the tax rate causes a 1.06 percent increase in the change in the growth rate of savings account deposits. This result is consistent with the introduction of exemptions for such accounts, as increases in the tax cause individuals to substitute away from checking toward savings accounts. Because the models are based on the growth rate of checking accounts but changes in the growth rate of savings accounts, we cannot be sure that the reduction in checking account deposits is offset by the increase in savings account deposits. It is likely that although some balances were transferred into savings accounts, some actually left the Colombian banking system. 
Table 11. Model B: VAR with $\Delta \ln ($ cash $)$ as a measure of money demand

\begin{tabular}{|c|c|c|c|}
\hline \multirow{2}{*}{$\begin{array}{l}\text { VAR w/ } \Delta \ln (\text { cash }) \\
\text { Lags and exogenous vars }\end{array}$} & \multicolumn{3}{|c|}{ Dependent Variables } \\
\hline & $\Delta \ln ($ cash $)$ & $\Delta^{2} \ln (r)$ & $\Delta^{2} \ln (\mathrm{GNP})$ \\
\hline L4. $\Delta \ln ($ cash $)$ & $-0.3391 * * *$ & -0.0724 & -0.0152 \\
\hline L3. $\Delta \ln ($ cash $)$ & $0.4000^{* * *}$ & $0.3414^{* *}$ & 0.0082 \\
\hline L2. $\Delta \ln (\operatorname{cash})$ & $0.1993 * *$ & -0.2076 & -0.0350 \\
\hline L1. $\Delta \ln ($ cash $)$ & $0.5227^{* * *}$ & 0.0960 & 0.0311 \\
\hline L4. $\Delta^{2} \ln (r)$ & $0.1699 * * *$ & -0.0669 & 0.0071 \\
\hline L3. $\Delta^{2} \ln (r)$ & $-0.1835 * * *$ & 0.0230 & 0.0004 \\
\hline L2. $\Delta^{2} \ln (r)$ & 0.0779 & 0.0762 & -0.0270 \\
\hline L1. $\Delta^{2} \ln (r)$ & -0.0723 & $0.3551 * * *$ & 0.0172 \\
\hline L4. $\Delta^{2} \ln (\mathrm{GNP})$ & $0.9832 * *$ & -0.6641 & -0.0421 \\
\hline L3. $\Delta^{2} \ln (\mathrm{GNP})$ & $1.1292 * * *$ & 0.2101 & $-0.2529 * *$ \\
\hline L2. $\Delta^{2} \ln (\mathrm{GNP})$ & 0.0977 & $1.1303 * *$ & -0.0488 \\
\hline L1. $\Delta^{2} \ln (\mathrm{GNP})$ & -0.1009 & $-1.1038 * *$ & -0.0370 \\
\hline$\Delta($ agro/GNP $)$ & 1.3839 & $3.9172 * *$ & -0.1461 \\
\hline$\Delta^{2} \ln ($ wage $)$ & 0.8342 & $1.5773^{*}$ & $-0.3352 * *$ \\
\hline$\Delta \operatorname{tax}$ & -0.0515 & -0.1336 & -0.0228 \\
\hline Constant & $0.0293 * * *$ & 0.0017 & 0.0026 \\
\hline Pseudo- $R^{2}$ & 0.7208 & 0.4284 & 0.1240 \\
\hline$p$-value for $F$ statistic & 0.0000 & 0.0000 & 0.5565 \\
\hline
\end{tabular}


Table 12. Model B: VAR with $\Delta \ln ($ checking) as a measure of money demand

\begin{tabular}{|c|c|c|c|}
\hline \multirow{2}{*}{$\begin{array}{l}\text { VAR w/ } \Delta \ln (\text { checking) } \\
\text { Lags and exogenous vars }\end{array}$} & \multicolumn{3}{|c|}{ Dependent Variables } \\
\hline & $\Delta \ln ($ checking $)$ & $\Delta^{2} \ln (r)$ & $\Delta^{2} \ln (\mathrm{GNP})$ \\
\hline L2. $\Delta \ln$ (checking) & $0.2169 * *$ & $0.2143 * *$ & -0.0156 \\
\hline L1. $\Delta \ln$ (checking) & $0.4551^{* * *}$ & 0.0990 & -0.0015 \\
\hline L2. $\Delta^{2} \ln (r)$ & -0.0035 & 0.0554 & -0.0094 \\
\hline L1. $\Delta^{2} \ln (r)$ & -0.1268 & $0.2287 * *$ & 0.0087 \\
\hline L2. $\Delta^{2} \ln (\mathrm{GNP})$ & 0.5866 & 0.6943 & -0.0135 \\
\hline L1. $\Delta^{2} \ln (\mathrm{GNP})$ & -0.0239 & $-1.4055 * * *$ & -0.0419 \\
\hline$\Delta($ agro $/ \mathrm{GNP})$ & $4.2927 * *$ & 1.8690 & 0.0096 \\
\hline$\Delta^{2} \ln ($ wage $)$ & -1.3698 & 0.4617 & -0.1674 \\
\hline$\Delta \operatorname{tax}$ & $-0.4173^{* * *}$ & 0.9333 & -0.0309 \\
\hline Constant & $0.0553 * * *$ & $-0.0205^{*}$ & 0.0033 \\
\hline Pseudo- $R^{2}$ & 0.6808 & 0.4682 & 0.0653 \\
\hline$p$-value for $F$ statistic & 0.0000 & 0.0000 & 0.6681 \\
\hline
\end{tabular}

Table 13. Model B: VAR with transf(M2-M1) as a measure of money demand

\begin{tabular}{lccc}
\hline & \multicolumn{3}{c}{ Dependent Variables } \\
\cline { 2 - 4 } $\begin{array}{l}\text { VAR w } / \text { Transf(M2-M1) } \\
\text { Lags and exogenous vars }\end{array}$ & Transf(M2-M1) & $\Delta^{2} \ln (r)$ & $\Delta^{2} \ln ($ GNP) \\
\hline L2. Transf(M2-M1) & $-0.3055^{* * *}$ & 0.0334 & 0.0971 \\
\hline L1. Transf(M2-M1) & $0.3660^{* * *}$ & 0.3256 & $-0.1550^{* *}$ \\
\hline L2. $\Delta^{2} \ln (r)$ & $0.0391^{*}$ & 0.0956 & -0.0124 \\
\hline L1. $\Delta^{2} \ln (r)$ & -0.0329 & $0.3397 * * *$ & 0.0006 \\
\hline L2. $\Delta^{2} \ln (\mathrm{GNP})$ & $-0.3782^{* * *}$ & $1.2633^{* *}$ & -0.0442 \\
\hline L1. $\Delta^{2} \ln (\mathrm{GNP})$ & -0.1392 & $-1.2510^{* *}$ & -0.0394 \\
$\Delta_{(\text {agro } / \mathrm{GNP})}$ & -0.0254 & $3.90755^{* *}$ & -0.0346 \\
$\Delta^{2} \ln ($ wage $)$ & -0.1354 & 1.1392 & -0.2182 \\
$\Delta_{\text {tax }}$ & -0.0260 & -0.1219 & -0.0198 \\
Constant & 0.0015 & $0.0196 * * *$ & 0.0013 \\
\hline Pseudo- $R^{2}$ & 0.2398 & 0.3628 & 0.1068 \\
\hline -value for $F$ statistic & 0.0004 & 0.0000 & 0.2441 \\
\hline Statistically significant at the $1 \%$ level $(* * *)$, at the $5 \%$ level $(* *)$, and at the $10 \%$ level $(*)$. \\
\hline
\end{tabular}


Table 14. Model B: VAR with $\Delta^{2} \ln (\mathrm{M} 2-\mathrm{M} 1)$ as a measure of money demand

\begin{tabular}{|c|c|c|c|}
\hline \multirow{2}{*}{$\begin{array}{l}\text { VAR } \mathrm{w} / \Delta^{2} \ln (\mathrm{M} 2-\mathrm{M} 1) \\
\text { Lags and exogenous vars }\end{array}$} & \multicolumn{3}{|c|}{ Dependent variables } \\
\hline & $\Delta^{2} \ln (\mathrm{M} 2-\mathrm{M} 1)$ & $\Delta^{2} \ln (r)$ & $\Delta^{2} \ln (\mathrm{GNP})$ \\
\hline L2. $\Delta^{2} \ln (\mathrm{M} 2-\mathrm{M} 1)$ & $-0.3285 * * *$ & -0.3722 & -0.0356 \\
\hline L1. $\left.\Delta^{2} \ln (\mathrm{M} 2-\mathrm{M} 1)\right)$ & 0.0223 & 0.2196 & $-0.1138 * * *$ \\
\hline L2. $\Delta^{2} \ln (r)$ & $0.0735 * *$ & 0.1048 & -0.0071 \\
\hline L1. $\Delta^{2} \ln (r)$ & 0.0149 & $0.3455 * * *$ & 0.0089 \\
\hline L2. $\Delta^{2} \ln (\mathrm{GNP})$ & -0.2299 & $1.2348 * *$ & -0.0368 \\
\hline L1. $\Delta^{2} \ln (\mathrm{GNP})$ & -0.2035 & $-1.5382 * * *$ & -0.0550 \\
\hline$\Delta($ agro $/ \mathrm{GNP})$ & -0.3753 & $3.634^{* *}$ & -0.1246 \\
\hline$\Delta^{2} \ln ($ wage $)$ & -0.1247 & 0.8607 & $-0.2683^{*}$ \\
\hline$\Delta \operatorname{tax}$ & $0.1059 * *$ & -0.1272 & -0.0046 \\
\hline Constant & -0.0020 & $0.0195 * * *$ & 0.0008 \\
\hline Pseudo- $R^{2}$ & 0.1915 & 0.3739 & 0.1145 \\
\hline$p$-value for $F$ statistic & 0.0068 & 0.0000 & 0.1908 \\
\hline
\end{tabular}

Figures 4 and 5, respectively, show impulse response functions for the growth rate of checking account balances and for changes in the growth rate of savings account balances. The growth rate of checking account balances decreases in response to an increase in the tax, then trends back to the long-run equilibrium. Although the growth rate of checking account balances returns to what it was before the tax increase, the reduction in account balances is permanent; balances would have grown faster for 30 months if not for the tax increase. The change in the growth rate of savings accounts exceeds its pre-tax-increase level for 30 months before returning to its long-run equilibrium. 
Figure 4. Impulse-response for checking account balances

Impulse-response function for the growth rate of checking account balances $(\Delta \ln ($ checking $))$ to a permanent 0.1 point increase in the tax rate

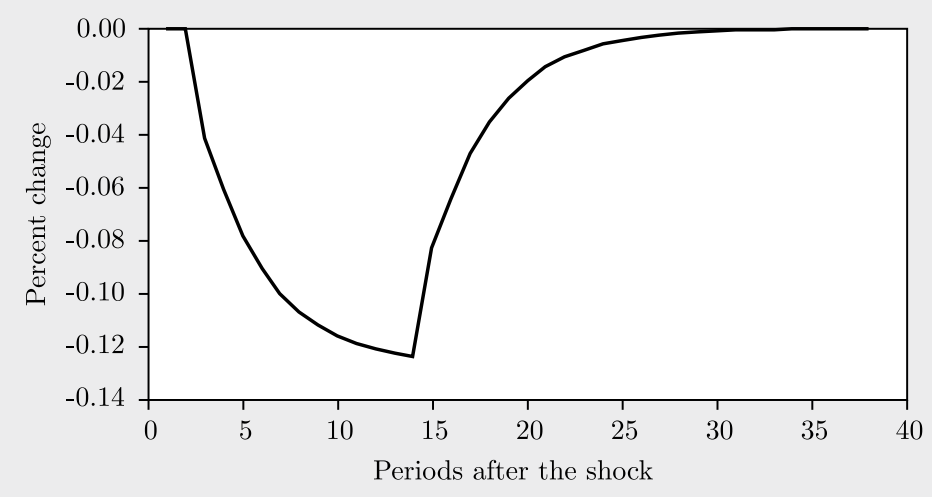

Note: The shock occurs in Period 3.

Figure 5. Impulse-response for savings account balances Impulse-response function for changes in the growth rate of savings account balances $\left(\triangle 2 \ln \left(M_{2}-M 1\right)\right)$ to a permanent 0.1 point increase in the tax rate

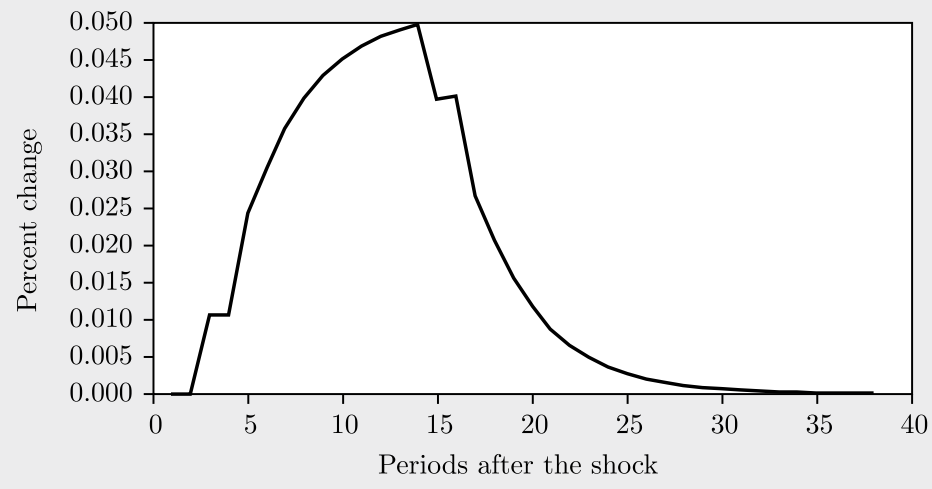

Note: The shock occurs in Period 3. 


\section{CONCLUSION}

Some countries in Latin America have introduced a bank debit tax in order to increase revenue. The tax has usually been levied in periods of economic turbulence. This paper analyzes the effects of such a tax on real cash holdings and on balances of different types of bank accounts in Colombia.

We find evidence of disintermediation, but no evidence of a substitution effect from any kind of bank account toward cash holdings. There is evidence, however, that the tax does increase the change in the growth rate of savings account balances, indicating a substitution effect between types of bank accounts. This effect is seen in Model $\mathrm{B}$, which considers only data beginning in 2000 .

This paper is not able to measure whether the increase in savings account balances corresponds to the entire decrease in checking account balances. Nevertheless, the results imply that the tax has caused some exodus of money from the financial sector, since the effect on checking account balances is large and negative. The presence of disintermediation can have serious detrimental effects on the growth potential of the country.

Only checking account balances show changes in both models, and these are always negative. A complete analysis of the effects of the tax on other investments like stocks and bonds is left for future research. However, the stock and bond markets in Colombia are rather limited and most individuals do not have access to them. Even though interest rates in Colombia are now lower due to improved financial and political stability, the outflow of capital reduces the amount available for investment in a country with extremely high financial services costs. The additional increase in the cost of capital generated by the tax on financial transactions has introduced efficiency problems into the Colombian banking sector. 


\section{REFERENCES}

Barro, R.J. (1976), "Integral constraints and aggregation in an inventory model of money demand." The Journal of Finance 31(1): 77-88.

Cárdenas, P. (2001a), "3*1000: A nadar en efectivo." La Semana Económica 292, Asobancaria. [3*1000: Swimming in Cash]

. (2001b), "Gravamen a los movimientos financieros: 3 años después." La Semana Económica 335, Asobancaria. [Bank Debit Taxes: 3 Years Later] . (2002), "Gravamen a los movimientos financieros: Un freno al crecimiento." La Semana Económica 362, Asobancaria. [Bank Debit Taxes: a Problem for Growth]

Clavijo, S. (2005), "Tributación, equidad y eficiencia en Colombia: Guía para salir de un sistema tributario amalgamado." Borradores de Economia 325, Banco de la República de Colombia. [Taxes, Equity and Efficiency in Colombia: a Guide to Simplify a Convoluted Tax System]

Coelho, I., L. Ebrill, and V. Summers (2001), "Bank Debit Taxes in Latin America: An Analysis of Recent Trends." IMF Working Paper.

Labán, R. (1991), "La hipótesis de cointegración y la demanda por dinero en Chile: 1974-1988." Cuadernos de Economía No. 83: 169-88. [The Hypothesis of Cointegration and Money Demand in Chile: 1974-1988]

Lozano, I.E. and J. Ramos (2000), "Análisis sobre la incidencia del impuesto del $2 * 1000$ a las transacciones financieras." Borradores de Economía, Banco de la República de Colombia. [Analysis of the Effects of the 2*1000 Tax on Financial Transactions]

Rodríguez, J.A. (2002), "El impuesto a las operaciones financieras y la equidad tributaria." Revista Cuadernos de Economía 21(37): 1-21, Universidad Nacional de Colombia. [The tax on Financial Transactions and Tax Fairness]

Saving, T.R. (1971), "Transaction costs and the demand for money." The American Economic Review 61(3): 407-420.

. (1976), "Transactions cost functions and the inventory-theoretic approach to money demand." Journal of Money, Credit and Banking 8(3): 339-45.

Valero, H.J. (2006), "Generalidades del gravamen a los movimientos financieros (GMF) en Colombia." Cuadernos de Trabajo, Oficina de Estudios Economicos, DIAN. [Discussion of Bank Debit Taxes in Colombia] 


\section{APPENDIX}

Table A1. Exemptions

\begin{tabular}{cc} 
(in US dollars) & \\
\hline Year & Real amount \\
\hline 2001 & $2,075.12$ \\
2002 & $2,108.13$ \\
2003 & $2,114.28$ \\
2004 & $2,614.56$ \\
2005 & $2,637.86$ \\
2006 & $2,688.17$ \\
2007 & $2,748.57$ \\
Source: DIAN . & \\
Base period: december 1998. \\
\hline
\end{tabular}

